\title{
Efficacy of lifestyle interventions in reducing diabetes incidence in patients with impaired glucose tolerance: a systematic review of randomized controlled trials
}

\author{
Uzung Yoon", Lai Lai Kwok ${ }^{2 *}$, Athanasios Magkidis ${ }^{3}$ \\ From Metabolism, diet and disease \\ Washington, DC, USA. 29-31 May 2012
}

\section{Background}

Every year over 3.8 million people are dying of diabetes and its complications. Lifestyle intervention was suggested to have beneficial effects in preventing and reducing diabetes incidence. Especially interventions in patients with impaired glucose tolerance (IGT), who belong to a high risk group in developing diabetes, are supposed to be very effective. According to the evidence heirarchy, a 1a level of evidence is missing and therefore a systematic review verifying the efficacy of lifestyle intervention is needed.

\section{Materials and methods}

Systematic review: The electronic database PubMed, Embase, Cochrane Central Register of Controlled Trials, Cochrane Database of Systematic Reviews, and Health Technology Assessment database were searched. Main inclusion criteria were randomized controlled trials, impaired glucose tolerance, lifestyle intervention with control group and observation time $>6$ month. Outcome measures were all diabetes events, as defined by the authors of each study, all-cause mortality, diabetes mortality, and quality adjusted life years (QALY). Two independent reviewers abstracted the found studies by title, abstract and full-text analysis. Furthermore the reporting quality of each study was assessed by using the CONSORT criteria (Consolidated Standards of Reporting Trials) and the methodological quality by SIGN 50 instrument (Scottish Intercollegiate Guidelines Network methodology checklist for randomized controlled trials). The primary outcome measure was diabetes incidence. Secondary outcome

\footnotetext{
${ }^{2}$ Columbia University, New York, NY, 10027, USA

Full list of author information is available at the end of the article
}

measures were overall mortality, disease-specific mortality, quality adjusted life years (QALY), and clinical parameters; body mass index (BMI), weight change, blood pressure, blood parameter, smoking, alcohol consumption.

\section{Results}

7 trials which included 25 relevant publications were identified [1-25]. Kappa Cohens for title-analysis were $\mathrm{K}=0.77, \quad(\mathrm{CI}=0.71-0.83)$, abstract-analysis $\mathrm{K}=0.81$ $(\mathrm{CI}=0.64-0.92)$ and full-text analysis $\mathrm{K}=0.78(\mathrm{CI}=0.57$ $0.98)$. Overall 5663 patients were analyzed with primary follow-up time: India (3 yr), Japan (4 yr), Sweden $(5 \mathrm{yr})$, Da Qing (6 yr), SIM (3 yr), DPP (5 yr), DPS (4 yr) and drop-out rate ranges from $5 \%$ to $28 \%$. Diabetes incidence ranges from $3 \%$ to $46 \%$ in the intervention group and $9.3 \%$ to $67.7 \%$ in the control group. The India study reported $A R R=16 \%, R R R=29 \%(p=0.018)$, Japan: $A R R=$ $6.3 \%, R R R=65 \%(\mathrm{p}<0.001)$, Sweden: $A R R=4 \%, R R R=$ $25 \%$ ( $\mathrm{p}=$ not significant), Da Qing: $A R R=22 \%, R R R=32 \%$ $(\mathrm{p}<0.05)$, SLIM: $A R R=20 \%, R R R=53 \%(\mathrm{p}=0.025), \mathrm{DPP}$ : $A R R=15 \%, R R R=58 \%$ (significant, no $p$ value reported), and DPS: $A R R=12 \%, R R R=52 \%$ (significant, no $p$ value reported). Mortality and morbidity were only analyzed in Da Qing study which showed no statistical differences (overall mortality: HRR 0.96, CI 0.65-1.41, CVD-mortality: HRR 0.83; CI 0.48-1.40, CVD event: HRR 0.98; CI 0.71-1.37).

\section{Conclusions}

Under consideration of heterogeneity in lifestyle interventions and follow up time of the included studies, this systematic review illustrated that lifestyle intervention can have a beneficial effect on the incidecne of diabetes 
in patients with impaired glucose tolerance. However, several studies found the effect of lifestyle intervention decreased after intervention was terminated. Development of standardized lifestyle intervention program is strongly needed and further long term intervention trials using this program are crucial in evidencing the long term efficacy.

\section{Author details}

'Berlin School of Public Health, Charité, Berlin, 11055, Germany. ${ }^{2}$ Columbia University, New York, NY, 10027, USA. ${ }^{3}$ Klinikum Mitte, Bielefeld, 33604, Germany.

Published: 1 June 2012

\section{References}

1. Ramachandran A, Snehalatha C, Mary S, Bhaskar AD, Vijay V: The Indian Diabetes Prevention Programme shows that lifestyle modification and metformin prevent type 2 diabetes in Asian Indian subjects with impaired glucose tolerance (IDPP-1). Diabetologia 2006, 49:289-297.

2. Kosaka K, Noda M, Kuzuya T: Prevention of type 2 diabetes by lifestyle intervention: a Japanese trial in IGT males. Diabetes Res Clin Pract 2005, 67:152-162.

3. Lindahl B, Nilssön TK, Borch-Johnsen K, Røder ME, Söderberg S, Widman L, Johnson $\mathrm{O}$, Hallmans $\mathrm{G}$, Jansson JH: A randomized lifestyle intervention with 5-year follow-up in subjects with impaired glucose tolerance: Pronounced short-term impact but long-term adherence problems. Scand I Public Health 2009, 37:434-442.

4. Pan XR, Li GW, Hu YH, Wang JX, Yang WY, An ZX, Hu ZX, Lin J, Xiao JZ, Cao HB, Liu PA, Jiang XG, Jiang YY, Wang JR, Zheng $H$, Zhang $H$, Bennett PH, Howard BV: Effects of diet and exercise in preventing NIDDM in people with impaired glucose tolerance. The Da Qing IGT and Diabetes Study. Diabetes Care 1997, 20:537-544.

5. Li G, Zhang P, Wang J, Gregg EW, Yang W, Gong Q, Li H, Li H, Jiang $Y$, An Y, Shuai Y, Zhang B, Zhang J, Thompson TJ, Gerzoff RB, Roglic G, Hu Y, Bennett PH: The long-term effect of lifestyle interventions to prevent diabetes in the China Da Qing Diabetes Prevention Study: a 20-year follow-up study. Lancet 2008, 371:1783-1789.

6. Li G, Hu Y, Yang W, Jiang Y, Wang J, Xiao J, Hu Z, Pan X, Howard BV, Bennett PH, DA Qing IGT, Diabetes Study: Effects of insulin resistance and insulin secretion on the efficacy of interventions to retard development of type 2 diabetes mellitus: The DA Qing IGT and Diabetes Study. Diabetes Res Clin Pract 2002, 58:193-200.

7. Roumen C, Corpeleijn E, Feskens EJ, Mensink M, Saris WH, Blaak EE: Impact of 3-year lifestyle intervention on postprandial glucose metabolism: the SLIM study. Diabet Med 2008, 25:597-605.

8. Corpeleijn E, Feskens EJ, Jansen EH, Mensink M, Saris WH, Blaak EE: Lifestyle intervention and adipokine levels in subjects at high risk for type 2 diabetes: the Study on Lifestyle intervention and Impaired glucose tolerance Maastricht (SLIM). Diabetes Care 2007, 30:3125-3127.

9. Mensink M, Blaak EE, Corpeleijn E, Saris WH, de Bruin TW, Feskens EJ: Lifestyle intervention according to general recommendations improves glucose tolerance. Obes Res 2003, 11:1588-1596.

10. Mensink M, Corpeleijn E, Feskens EJ, Kruijshoop M, Saris WH, de Bruin TW, Blaak EE: Study on lifestyle-intervention and impaired glucose tolerance Maastricht (SLIM): design and screening results. Diabetes Res Clin Pract 2003, 61:49-58

11. The Diabetes Prevention Program Research Group: The Diabetes Prevention Program: description of lifestyle intervention. Diabetes Care 2002, 25:2165-2171.

12. Knowler WC, Barrett-Connor E, Fowler SE, Hamman RF, Lachin JM, Walker EA, Nathan DM, Diabetes Prevention Program Research Group: Reduction in the incidence of type 2 diabetes with lifestyle intervention or metformin. N Engl J Med 2002, 346:393-403.

13. The Diabetes Prevention Program Research Group: The Diabetes Prevention Program: design and methods for a clinical trial in the prevention of type 2 diabetes. Diabetes Care 1999, 22:623-634.
14. The Diabetes Prevention Program Research Group: The Diabetes Prevention Program: baseline characteristics of the randomized cohort. The Diabetes Prevention Program Research Group. Diabetes Care 2000, 23:1619-1629.

15. Kitabchi AE, Temprosa M, Knowler WC, Kahn SE, Fowler SE, Haffner SM, Andres R, Saudek C, Edelstein SL, Arakaki R, Murphy MB, Shamoon H, Diabetes Prevention Program Research Group: Role of insulin secretion and sensitivity in the evolution of type 2 diabetes in the diabetes prevention program: effects of lifestyle intervention and metformin. Diabetes 2005, 54:2404-2414.

16. Herder C, Peltonen $M$, Koenig W, Sütfels K, Lindström J, Martin S, llanneParikka P, Eriksson JG, Aunola S, Keinänen-Kiukaanniemi S, Valle T, Uusitupa M, Kolb H, Tuomilehto J, Finnish Diabetes Prevention Study Group: Anti-inflammatory effect of lifestyle changes in the Finnish Diabetes Prevention Study. Diabetologia 2009, 52:433-442.

17. Ilanne-Parikka P, Eriksson JG, Lindstrom J, Peltonen M, Aunola S, Hämäläinen H, Keinänen-Kiukaanniemi S, Laakso M, Valle T, Lahtela J, Uusitupa M, Tuomilehto J, Finnish Diabetes Prevention Study Group: Effector lifestyle intervention on the occurrence of metabolic syndrome and its components in the finnish diabetes prevention study. Diabetes Care 2008, 31:805-807.

18. Laaksonen DE, Lindstrom J, Lakka TA, Eriksson JG, Niskanen L, Wikström K, Aunola S, Keinänen-Kiukaanniemi S, Laakso M, Valle T, llanne-Parikka P, Louheranta A, Hämäläinen $H$, Rastas M, Salminen V, Cepaitis Z, Hakumäki M, Kaikkonen $H$, Härkönen P, Sundvall J, Tuomilehto J, Uusitupa M, Finnishdiabetes prevention study: Physical activity in the prevention of type 2 diabetes: the Finnish diabetes prevention study. Diabetes 2005, 54:158-165.

19. Tuomilehto J, Lindstrom J, Eriksson JG, Valle $\Pi$, Hämäläinen $H$, llanneParikka P, Keinänen-Kiukaanniemi S, Laakso M, Louheranta A, Rastas M Salminen V, Uusitupa M, Finnish Diabetes Prevention Study Group: Prevention of type 2 diabetes mellitus by changes in lifestyle among subjects with impaired glucose tolerance. N Engl J Med 2001, 344:1343-1350.

20. Lindstrom J, llanne-Parikka P, Peltonen M, Aunola S, Eriksson JG, Hemiö K, Hämäläinen $\mathrm{H}$, Härkönen $\mathrm{P}$, Keinänen-Kiukaanniemi S, Laakso $\mathrm{M}$, Louheranta A, Mannelin M, Paturi M, Sundvall J, Valle TT, Uusitupa M, Tuomilehto J, Finnish Diabetes Prevention Study Group: Sustained reduction in the incidence of type 2 diabetes by lifestyle intervention: follow-up of the Finnish Diabetes Prevention Study. Lancet 2006, 368:1673-1679.

21. Herder C, Peltonen M, Koenig W, Kräft I, Müller-Scholze S, Martin S, Lakka T, llanne-Parikka P, Eriksson JG, Hämäläinen $H$, Keinänen-Kiukaanniemi S, Valle TT, Uusitupa M, Lindström J, Kolb H, Tuomilehto J: Systemic immune mediators and lifestyle changes in the prevention of type 2 diabetes: results from the Finnish Diabetes Prevention Study. Diabetes 2006, 55:2340-2346.

22. Uusitupa M, Louheranta A, Lindstrom J, Valle T, Sundvall J, Eriksson J, Tuomilehto J: The Finnish Diabetes Prevention Study. Br J Nutr 2000, 83:137-142.

23. Lindstrom J, Louheranta A, Mannelin M, Rastas M, Salminen V, Eriksson J, Uusitupa M, Tuomilehto J, Finnish Diabetes Prevention Study Group: The Finnish Diabetes Prevention Study (DPS): Lifestyle intervention and 3year results on diet and physical activity. Diabetes Care 2003, 26:3230-3236.

24. Lindstrom J, Eriksson JG, Valle T., Aunola S, Cepaitis Z, Hakumäki M, Hämäläinen $\mathrm{H}$, Ilanne-Parikka $\mathrm{P}$, Keinänen-Kiukaanniemi S, Laakso $\mathrm{M}$, Louheranta A, Mannelin M, Martikkala V, Moltchanov V, Rastas M, Salminen V, Sundvall J, Uusitupa M, Tuomilehto J: Prevention of diabetes mellitus in subjects with impaired glucose tolerance in the Finnish Diabetes Prevention Study: results from a randomized clinical trial. J Am Soc Nephrol 2003, 14:108-113.

25. Eriksson J, Lindstrom J, Valle T, Aunola $\mathrm{S}$, Hämäläinen $\mathrm{H}$, llanne-Parikka $\mathrm{P}$, Keinänen-Kiukaanniemi $S$, Laakso $M$, Lauhkonen $M$, Lehto $P$, Lehtoner $A$, Louheranta A, Mannelin M, Martikkala V, Rastas M, Sundvall J, Turpeinen A, Viljanen T, Uusitupa M, Tuomilehto J: Prevention of Type II diabetes in subjects with impaired glucose tolerance: the Diabetes Prevention Study (DPS) in Finland. Study design and 1-year interim report on the feasibility of the lifestyle intervention programme. Diabetologia 1999, 42:793-801. 
doi:10.1186/1753-6561-6-S3-P28

Cite this article as: Yoon et al:: Efficacy of lifestyle interventions in reducing diabetes incidence in patients with impaired glucose tolerance: a systematic review of randomized controlled trials. BMC Proceedings 2012 6(Suppl 3):P28.

Submit your next manuscript to BioMed Central and take full advantage of:

- Convenient online submission

- Thorough peer review

- No space constraints or color figure charges

- Immediate publication on acceptance

- Inclusion in PubMed, CAS, Scopus and Google Scholar

- Research which is freely available for redistribution

Submit your manuscript at www.biomedcentral.com/submit 